Jacob W. Wood

\title{
Forging the Analogy of Being
}

\author{
John of La Rochelle's De divinis nominibus (Trier, Abtei St. \\ Matthias, 162) and the Summa Halensis on Knowing and Naming \\ God
}

\begin{abstract}
This chapter studies the shift from equivocity and univocity towards analogy in treatises on the divine names in late 12 th and early $13^{\text {th }}$-century Summae through an analysis of questions 1-4 of John of La Rochelle's De divinis nominibus and the corresponding sections of the Summa Halensis. It documents how in the De divinis nominibus, John selectively edits William of Auxerre's Summa aurea in order to introduce the metaphysics of causality into the traditional treatise on the divine names. This initially led John to formulate an analogy of being which accommodated earlier approaches to divine predication by adhering to the modus significandi of concrete names, but using the metaphysics of causality to deny that their res significata could be applied directly to God. Subsequently, the editor of Book 1 of the Summa Halensis-likely John himself-took a more kataphatic approach to the analogy of being. Although he preserved John's earlier use of the res/modus distinction in the case of negative names, he reversed it for names of eminence, denying the modus significandi of concrete names, but using the metaphysics of causality to affirm that their res significata could be predicated proprie of God.
\end{abstract}

\section{Introduction}

Since medieval authors generally considered the writings of Pseudo-Dionysius to have been the genuine literary products of Paul's convert at the Areopagus, and since they had access to the text of Pseudo-Dionysius' Divine Names from the $9^{\text {th }}$ century onwards, ${ }^{1}$ the Divine Names exercized a commanding influence over the philos-

1 For a discussion of the manuscripts of Dionysius available to medieval scholastics, see H.F. Dondaine, Le corpus dionysien de l'Université de Paris au XIIIe siècle (Rome: Edizioni di storia e letteratura, 1953); Timothy Budde, 'The Versio Dionysii of John Scottus Eriugena: A Study of the Manuscript Tradition and Influence of Eriugena's Translation of the Corpus Areopagiticum from the $9^{\text {th }}$ through the $12^{\text {th }}$ Century' (PhD thesis, Pontifical Institute of Medieval Studies, 2011); Gioacchino Curiello, “"Alia translatio melior est”: Albert the Great and the Latin Translations of the Corpus Dionysiacum,' Documenti E Studi Sulla Tradizione Filosofica Medievale 14 (2013): 121-51; Bernard Blankenhorn, The Mystery of Union with God: Dionysian Mysticism in Albert the Great and Thomas Aquinas (Washington, DC: The Catholic University of America Press, 2015), 30 - 46. Editions of the translations available to the medievals can be found in Pseudo-Dionysius, Dionysiaca, ed. Philippe Chevallier, vol. 1 (Paris: Desclee de Brouwer, 1937).

D OpenAccess. (c) 2020 Lydia Schumacher, published by De Gruyter. (cc))BY-NC-ND This work is licensed under the Creative Commons Attribution-NonCommercial-NoDerivatives 4.0 License. 
ophy and theology of the Latin Middle Ages. ${ }^{2}$ While some later authors wrote direct commentaries on the text, ${ }^{3}$ many more simply incorporated the text alongside-and often above-other auctoritates within the context of their other theological work. It was a challenging task. For theology is, at its root, an exercise in knowing and naming God, and so Pseudo-Dionysius raised for theologians of the Latin Middle Ages what we would today describe as 'meta-questions' about how the discipline of theology functions at all.

The home which these meta-questions tended to find in the late $12^{\text {th }}$ and early $13^{\text {th }}$ centuries was among the many Summae of theology that were then coming into existence. Although they do not figure heavily in the text of Peter Lombard's Sententiae in IV libris distinctae, ${ }^{4}$ one can find extensive treatments of the divine names throughout many of the other, lesser-known Summae of the period. Louisa Valente has noted that in some texts, such as the Summae of Peter of Poitiers, Praepositinus

2 On the reception history of Pseudo-Dionysius in the Middle Ages, see the sources cited in Jan Aertsen, Medieval Theology as Transcendental Thought: From Philip the Chancellor (ca. 1225) to Francisco Suárez (Boston: Brill, 2012), 101, n. 173. To these may be added Jean Leclerq, 'Influence and non-Influence of Dionysius in the Western Middle Ages,' in Pseudo-Dionysius, The Complete Works (New York: Paulist Press, 1987), 25-32; Paul Rorem, Pseudo-Dionysius: A Commentary on the Texts and an Introduction to Their Influence (New York: Oxford University Press, 1993); Paul Rorem, 'The Early Latin Dionysius: Eriugena and Hugh of St Victor,' in Re-Thinking Dionysius the Areopagite, ed. Sarah Coakley and Charles Stang (New York: Wiley-Blackwell, 2011), 71-84; Boyd Taylor Coolman, 'The Medieval Affective Dionysian Tradition,' in Re-Thinking Dionysius the Areopagite, 85-102. 3 Direct commentaries are more common on the Celestial Hierarchy than they are on the Divine Names. The two principal commentaries on this work are those of John Scottus Eriugena and Hugh of St Victor. For the text of Eriugena's commentary on the Celestial Hierarchy, see John Scottus Eriugena, Expositiones in ierarchiam coelestem, ed. Jeanne Barbet, Corpus Christianorum Continuatio Mediaevalis, 31 (Turnholt: Brepols, 1975). For the text of Hugh of St Victor's commentary on the same work, see Hugh of St Victor, Super Ierarchiam Dionysii, ed. Dominique Poirel, Corpus Christianorum Continuatio Mediaevalis, 178 (Turnholt: Brepols, 2015). Direct commentaries on the Divine Names do not appear to begin in earnest until after Thomas Gallus. For the text of Gallus' commentary, see Thomas Gallus, Explanatio in libros Dionysii, ed. Declan Anthony Lawell, Corpus Christianorum Continuatio Mediaevalis, 223 (Turnholt: Brepols, 2011). After Gallus, commentaries appear in quick succession by Robert Grosseteste, Albert the Great, and Thomas Aquinas. Until the completion of the critical edition of Grosseteste's commentary by Gioacchino Curiello, a critical edition of Grosseteste's commentary remains a significant desideratum. For Albert, see Albertus the Great, Super Dionysium De divinis nominibus, ed. Paulus Simon (Münster: Aschendorff, 1972); for Thomas, the best edition remains Thomas Aquinas, In librum Beati Dionysii De divinis nominibus expositio, ed. Ceslas Pera, Pietro Caramello, and Carlo Mazzantini (Turin: Marietti, 1950).

4 Peter Lombard treats the divine names in Sentences 1, d. 8 and d. 22. For the text of these distinctions, see Peter Lombard, Sententiae in IV libris distinctae, vol. 1, ed. Ignatius Brady, 3rd ed. (Grottaferrata: Editiones Collegii S. Bonaventurae, 1971), 95-103 and 178-80. Although Peter Lombard's treatment of the divine names compared to those of his contemporaries might appear to be somewhat cursory, it must be borne in mind that, since the Sentences were the fruit of oral teaching, the edition of the Sentences which we possess should by no means be considered Peter's 'definitive' text. See Mark Clark, 'Peter Lombard, Stephen Langton, and the School of Paris: The Making of the TwelfthCentury Scholastic Biblical Tradition,' Traditio 72 (2017): 3-4 and 80-1. 
of Cremona, and Stephen Langton, the discussion of the divine names is so central that it provides the ordering principle for trinitarian theology as a whole. ${ }^{5}$ Yet even when the structure of the text is not determined by its treatment of the divine names, other texts from the period, such as the Summae of Robert of Melun, Simon of Tournai, and Alan of Lille, as well as the anonymous Summa Sententiarum, the Summa Zwettlensis, and the Tractatus Invisibilia Dei, contain detailed and often extensive treatments of the topic. ${ }^{6}$ All of these works are trying to grapple with the paradox at the heart of Dionysian thought: how are we to know and name a God who lies fundamentally beyond all affirmation and negation?

Late $12^{\text {th }}$-century theologians typically attempted to describe the paradox of divine affirmation and negation by means of a twofold movement: an upward movement of translatio, in which terms spoken properly of creatures were emptied of their creaturely meaning and applied translative to God with the rules of revealed doctrine; and a downward movement which they called by various names, and in which terms spoken proprie of God were borrowed for use among creatures. ${ }^{7}$ Within this discussion, there were two poles in relation to which later theologians would place themselves. One extreme was that of equivocity, in which all theological speech

5 Louisa Valente, Logique et théologie: Les écoles parisiennes entre 1150 et 1220 (Paris: J. Vrin, 2007), 337: '[L]a classification des noms divins n'est pas seulement située au début de la Summa, elle fournit aussi le principe autour duquel le traitement des thématiques trinitaires est bâti.' See Book 1 of Peter of Poitiers' Summa, the text of which can be found in Peter of Poitiers, Sententiae Petri Pictaviensis, ed. Philip Moore and Marthe Dulong, vol. 1 (Notre Dame, IN: University of Notre Dame Press, 1943); Book 1 of Praepositinus of Cremona's Summa Qui producit ventos, the text of which can be found in Giuseppe Angelini, L'Ortodossia e la grammatica: Analisi di struttura e deduzione storica della teologia Trinitaria di Prepositino (Rome: Università Gregoriana, 1972), 191-303; and the first part of Stephen Langton's Summa, the text of which can be found in Sten Ebbesen and Lars Mortensen, 'A Partial Edition of Stephen Langton's Summa and Quaestiones with Parallels from Andrew Sunesen's Hexaemeron,' Cahiers de l'Institut du Moyen-Âge Grec et Latin 49 (1985): 37-134.

6 See Book 1, Part 3 of the Summa of Robert of Melun, the text of which can be found in Robert of Melun, Oeuvres de Robert de Melun, ed. Raymond Martin, vol. 3/2 (Louvain: Spicilegium Sacrum Lovaniense, 1952), 1-97; the questions on the divine names in the Summa of Simon of Tournai, a witness to the text of which can be found in Paris, Bibliothèque nationale de France, lat. 14886, fols 3vb-9ra; in passim throughout the Summa Quoniam Homines of Alan of Lille, the text of which can be found in Palémon Glorieux, 'La Somme “Quoniam Homines” d'Alain de Lille,' Archives d'histoire doctrinale et littéraire du Moyen Age 20 (1953): 119-359; Book 1, Chapters 7 and 9 to 10 of the Summa Sententiarum, the text of which can be found in PL 176:52D-54C, 55B-58D; Book 1 of the Summa Zwettlensis, the text of which can be found in Nikolaus M. Häring, Die Zwettler Summe: Einleitung und Text (Münster: Aschendorff, 1977), 34-77; and in passim throughout the Tractatus Invisibilia Dei, the text of which is available in Niklaus M. Häring, 'The Treatise 'Inuisibilia Dei' in MS Arras, Bibl. mun. 981 (399),' Recherches de théologie ancienne et médiévale 40 (1973): 104-46.

7 On translatio, see Valente, Logique et théologie, 74. The most common label for the downward movement was denominatio (see Valente, Logique et théologie, 76-8). Valente points out that Alan of Lille abandoned the use of the label, denominatio, using translatio to describe both an upward and a downward movement. The subsequent tradition followed Alan (Valente, Logique et théologie, 219-20). 
follows an upward movement of translatio; this approach was given its classic expression for subsequent theologians by Alan of Lille. ${ }^{8}$ The other was that of univocity, in which all theological terms follow the downward movement outlined above; this approach was given its classic expression for subsequent theologians by Praepositinus of Cremona. ${ }^{9}$

Although in some ways Alan and Praepositinus set forth opposite approaches to the question of knowing and naming God, there was one important respect in which these earlier Summists agreed with one another: the signification of philosophical terms does not carry over into theology. For Alan, the words with which we name God may first be formed in the human disciplines and then carried over into theology, but their signification remains restricted by the human disciplines; we can only use them in theology because we seem to know more than we can say: the surface meaning of our words (the proprietas dicendi) only ever refers improprie to God, even if the sense that our words evoke beyond their metaphorical meaning (the proprietas essendi) refers proprie to God. ${ }^{10}$ For Praepositinus, there is no such divergence between our knowledge and our speech, but that is because the signification of the words with which we name God must first be formed in theology, and then borrowed by the human disciplines. ${ }^{11}$ This absence of any conscious reliance on the human disciplines for the signification of theological terms gives these earlier Summists an almost completely grammatical focus. They view the principal task of the theologian as delineating the 'rules' (regulae) according to which words, whose signification comes entirely from revealed doctrine, may be used in theological discourse. These rules could come from one of three places: from theological authority, from treatises on grammar, and from treatises on logic. ${ }^{12}$

By the mid $13^{\text {th }}$-century, equivocity and univocity gave way to a doctrine of analogy, in which-though individual theologians differed radically on the particulars-it was now supposed that the human disciplines could supply theological terms with

8 Alan of Lille, Summa Quoniam Homines 10 (Glorieux, 144-5). See Valente, Logique et théologie, $206-32$.

9 Although Praepositinus does not use the abstract noun univocitas or any of its cognates explicitly when he describes the thesis which later scholastics would associate with univocity in Summa Qui producit ventos 8.2 (Angelini, 248-51), Angelini, L'Ortodossia e la grammaticà, 135, recognizes it as a legitimate interpretation of Praepositinus' thought, going so far as to describe univocity as 'il postulato supremo' of Praepositinus' methodology.

10 Valente, Logique et théologie, 211-3.

11 Valente, Logique et théologie, 256.

12 The use of and interplay among these respective sources is not consistent among theologians of the period. Valente makes a basic distinction between Porretanians, who prefer reason to authority, and Lombardians, who bend reason to authority (see Valente, Logique et théologie, 19, 385-8). But if we consider Valente's argument that Stephen Langton marks the culmination of the late $12^{\text {th }}$-century grammatical tradition, in the light of Mark Clark's argument in 'Peter Lombard, Stephen Langton, and the School of Paris,' 22-48, that Langton should also be seen as the inheritor of the 'Lombardian' school, this suggests that Valente's basic division may need to be reconsidered. 
signification. ${ }^{13}$ Scholars have yet to pinpoint a precise moment when the shift occurred, ${ }^{14}$ but we see it in Book 1 of Albert the Great's Commentary on the Sentences and in Book 1 of the Summa Halensis, both completed in the mid-1240s. ${ }^{15}$ While these texts utilize different, and at times opposing branches of the Arabic-Aristotelian tradition to explain how one moves along the Dionysian triplex via from philosophy into theology, they are united in the idea that it can be done. The elevation of our phil-

13 Aertsen, Medieval Philosophy as Transcendental Thought, 8, following Jean-François Courtine, Inventio analogiae: Métaphysique et ontothéologie (Paris: J. Vrin, 2005), refers to this as the 'invention of analogy'.

14 The shift had causes both internal and external to the Latin tradition. Within the Latin tradition, Valente, Logique et théologie, 260-1, argues that this shift has in part to do with Stephen Langton's attempt to integrate Alan's equivocity with Praepositinus' univocity. For Langton, most theological terms follow Alan's paradigm, but there are some terms-which Langton calls superpredicamentalia-that share semantic content with their philosophical counterparts. According to Valente, Langton's superpredicamentalia effectively become the transcendentals in later authors.

While acknowledging the importance of superpredicamentalia within the Latin tradition (see Aertsen, Medieval Philosophy as Transcendental Thought, 45-6), Aertsen, Medieval Philosophy as Transcendental Thought, 75-6, points to the seminal influence of Avicenna's Prima Philosophia for the $13^{\text {th }}$-century paradigm shift, going so far as to say that it 'determined the medieval reading and reception of Aristotle's Metaphysics'. While Aertsen is more sanguine about the role of Avicenna specifically in the formulation of the medieval doctrine of the analogy of being (Aertsen, Medieval Philosophy as Transcendental Thought, 97), the conclusions reached below in this study provide evidence that Avicenna's influence on the formulation of this doctrine was more significant than Aertsen realized.

Amos Bertolacci, 'On the Latin Reception of Avicenna's Metaphysics before Albertus Magnus: An Attempt at Periodization,' in The Arabic Hebrew and Latin Reception of Avicenna's Metaphysics, ed. Dag Nikolaus Hasse and Amos Bertolacci (Boston: De Gruyter, 2012), 202-4, distinguishes three phases of the reception of Avicenna's Prima Philosophia: an initial, local reception confined to Toledo in the second half of the $12^{\text {th }}$ century, in which the Prima Philosophia is the principal text from the Aristotelian tradition on metaphysics; a wider reception in both Paris and Oxford through the 1230s, in which the Prima Philosophia is considered alongside, but secondarily to Aristotle's Metaphysics itself; and a final phase, seen especially in Oxford after 1240, in which the Prima Philosophia is considered not as an independent work but as an interpretation of Aristotle's Metaphysics, and in which Averroes' Long Commentary on the Metaphysics ascends to a greater level of influence than Avicenna's Prima Philosophia. The texts considered in this chapter date to Bertolacci's second and third periods. The use of Avicenna's Prima Philosophia in the doctrine of analogy in Summa Halensis, which we shall examine below, provides evidence of the continued importance of Avicenna in the third phase. 15 See Jacob W. Wood, 'Kataphasis and Apophasis in Thirteenth Century Theology: The Anthropological Context of the Triplex Via in the Summa fratris Alexandri and Albert the Great,' Heythrop Journal 57 (2016): 293-311. Aertsen, Medieval Philosophy as Transcendental Thought, 46-53, also points to the logical works of Albert the Great, which can be dated to the early 1250s, while Amos Bertolacci, 'A New Phase of the Reception of Aristotle in the Latin West: Albertus Magnus and His Use of Arabic Sources in the Commentaries on Aristotle,' in Albertus Magnus und der Ursprung der Universitätsidee: Die Begegnung der Wissenschaftskulturen im 13. Jahrhundert und die Entdeckung des Konzepts der Bildung durch Wissenschaft, ed. Ludger Honnefelder (Berlin: Berlin University Press, 2011), 259 - 76, 491500, provides a more general account of the reception of Avicenna's and Averroes' metaphysics in Albert's work. 
osophical language by analogy thus establishes not just rules, but even ideas which form the basis of theological thought, a presupposition which the earlier Summists had by and large rejected.

The goal of the present study is to document one part of the $13^{\text {th }}$ century shift towards analogy in questions 1-4 of the De divinis nominibus in MS Trier, Abtei St Matthias, 162. I will show how John of La Rochelle uses these questions to rework William of Auxerre's Summa Aurea in order to introduce the analogy of being into the traditional Tractatus de divinis nominibus. Although it would not be proper to speak of John's work as a direct 'source' for the Summa Halensis, given the fact that John himself was likely the principal editor of the corresponding section of the Summa Halensis, questions 1-4 of the De divinis nominibus of Trier 162 can be said to set a trajectory which the Summa Halensis later follows. In the De divinis nominibus, which John initially intended as a part of a larger Summa in the tradition of Alan of Lille and Praepositinus of Cremona, John incorporates the analogy of being into the traditional Tractatus de divinis nominibus in such a way as to preserve the apophatic character of divine naming: although our names for God are drawn from the human disciplines and applied to God by the via eminentiae, John uses the distinction between the res significata and the modus significandi of divine names to argue that we must detach their signification from creatures if we wish to name God with them. In the Summa Halensis, the editor continues to offer this formulation as the pattern according to which we use negative divine names, but argues that names of eminence use the res / modus distinction in the opposite manner to achieve a kataphatic result: we deny their concrete modus significandi, but apply their res significata to God proprie.

Since the text of John's De divinis nominibus has not previously been studied, it is necessary to begin with an analysis of the text itself. That analysis will establish it as the second part of the De articulis fidei by John of La Rochelle, originally intended for inclusion in John's unfinished Summa theologice discipline. After the nature of the text has been established, we can proceed to an analysis of John's understanding of analogy in the De divinis nominibus, and finally to a comparison with that of the Summa Halensis.

\section{The Text}

The manuscript, Trier, Abtei St Matthias, 162 , dates to the $14^{\text {th }}$ century. ${ }^{16}$ Beyond that, its provenance is unknown. Besides various insertions, notes, and outlines, it contains the following selection of philosophical and theological works:

16 See Max Keuffer, Beschreibendes Verzeichnis der Handschriften der Stadtbibliothek zu Trier, vol. 2 (Trier: Kommissionsverlag der Fr. Lintz'schen Buchhandlung, 1891), 78-9; Petrus Becker, Die Benediktinerabtei St. Eucharius-St. Matthias vor Trier, Das Erzbistum Trier, 8 (Berlin: De Gruyter, 1996), 139. In what follows, I will use Becker's foliation. 
- Anselm of Canterbury, Proslogion 24-26 (f. 1v-2r)

- John of La Rochelle, Summa de vitiis et peccatis (f. 5ra-89rb)

- Cassiodorus, De anima (f. 89va-91rb)

- Pseudo-Augustine, De spiritu et anima (91va-101rb)

- Augustine, De agone christiano (101va-106vb)

- Pseudo-Augustine, De ecclesiasticis dogmatibus (106vb-109va)

- John of La Rochelle, Tractatus de anima et virtutibus (109va-125vb) ${ }^{17}$

- John of La Rochelle, De divinis nominibus (125vb-142rb)

- John of La Rochelle, De articulis fidei, pt. 2 (142va-144ra)

- John of La Rochelle, Summa de anima (145ra-188ra)

- Gratian, Decretum, Table of Contents to p. 1 (188va-190vb)

The De divinis nominibus is not directly attributed to John in the manuscript. The rubricator has labeled it as the secunda pars tractatus de symbolis. Its incipit is more difficult to understand: sequitur pars secunda prime partis istius partis. ${ }^{18}$ This is actually an oblique reference to John's De articulis fidei. However, that fact can only be seen by comparing the two texts to one another.

As noted above, John originally planned the De articulis fidei as the first part of a Summa theologice discipline which he never fully completed. Doucet observes that John's Summa seems to have gone through approximately three redactions, and that the second and third redactions explicitly state that John planned to divide the work into six Summulae: a Summa de articulis fidei, a Summa de vitiis, a Summa de donis, a Summa de legibus et praeceptis, a Summa de virtutibus, and a Summa de sacramentis. ${ }^{19}$ While the De articulis fidei can therefore be referred to as a Summa or Summula in its own right, it can also be referred as the Prima Pars of the Summa theologice discipline.

The incipit of the De articulis fidei is traditionally given as Summa theologice discipline in duobus consistit, scilicet in fide et moribus. ${ }^{20}$ Those are the first words of the

17 The rubrication ascribes this Tractatus to 'Frater Od.' [=Odo Rigaldus?]. Pierre Michaud-Quantin, 'Introduction,' in John of La Rochelle, Tractatus de divisione multiplici potentiarum animae, ed. Pierre Michaud-Quantin (Paris: J. Vrin, 1964), 14, takes up the question of this rubrication, and presents on pages 14-16 the evidence that this work, and the Tractatus de divisione multiplici potentiarum animae which it contains, should be ascribed to John of La Rochelle. For a summary of evidence to the contrary, see Victorin Doucet, 'Prolegomena in librum III necnon in libros I et II "Summae Fratris Alexandri”,' in Doctoris irrefragabilis Alexandri de Hales Ordinis minorum Summa theologica, vol. 4 (Quaracchi: Collegium S. Bonaventurae, 1948), cCxII.

18 The combination of these two labels seemingly led Keuffer, Beschreibendes Verzeichnis der Handschriften der Stadtbibliothek zu Trier, 78-9, to conflate the text of the De divinis nominibus with the extract from John of La Rochelle's De articulis fidei which follows it; Petrus Becker, Die Benediktinerabtei St. Eucharius-St. Matthias vor Trier, 139, distinguishes the two texts but leaves both works ultimately unidentified.

19 Doucet, 'Prolegomena,' ccxiv.

20 Doucet, 'Prolegomena,' ccxiı. 
prologue to John's Summa as a whole, and since the De articulis fidei is the first part of that Summa, they are traditionally prepended to it. But this is misleading. After introducing the Summa as a whole and explaining its plan, John transitions to the De articulis fidei and gives the De articulis fidei a new incipit, based on Rom. 10:10. We will give the text in Latin for the sake of analysis:

De articulis vero fidei secundum formam Apostoli prosequendum est: Dicit enim ad Rom. X: Corde creditur ad iustiiam, ore autem confessio fit ad salutem. Et ideo de iis est prius agendum secundum quod corde credendi sunt; deinde secundum quod ore fideliter confiteri locutionibus catholicis et veris. ${ }^{21}$

Having distinguished those things which are to be believed in the heart from those which are to be confessed in words, John goes on say-without explaining exactly what he means-that the prima pars is divided into three further partes: a Commentary on the Apostle's Creed, a Commentary on the Nicene Creed, and a Commentary on the Athanasian Creed. ${ }^{22}$

In the prologue to the De divinis nominibus, John makes two direct references the prologue of the De articulis fidei. In the first sentence, he quotes its incipit. In the second, he refers to it by name, and picks up the distinction between what is believed with the heart and what is confessed in words.

Sequitur pars secunda prime partis istius partis: Sicut enim dicitur ad Romanos X: Corde creditur ad iustiiam ore autem confessio sit ad salutem. Dictum est in parte precedenti de hiis que debemus corde credere, scilicet de articulis fidei; modo restat inquisitio qualiter ea, que credimus, possimus ore fideliter confiteri. ${ }^{23}$

By comparing the two texts, we can see that the words istius partis in the incipit should be punctuated with a colon; the demonstrative pronoun istius refers forward to the quotation of the incipit to the De articulis fidei, naming that work by its incipit. In this case, the most natural reading of the incipit of the De divinis nominibus would

21 Doucet, 'Prolegomena,' ccxir: [We should now proceed to discuss the articles of faith according to the Apostle's plan. For he says in Romans 10:10, "We believe with the heart unto righteousness, but confess with the mouth unto salvation." For that reason, we should begin by discussing [the articles of faith] insofar as they should be believed with the heart; then, insofar as they are faithfully confessed with the mouth in terms which are catholic and true].

22 Doucet, 'Prolegomena,' ccxII. I am grateful to Riccardo Saccenti for allowing me to supplement Doucet's transcription with a pre-publication version of his own, more complete transcription of this work.

23 John of La Rochelle, De divinis nominibus, prol. (Trier, Abtei St Matthias, 162, fol. 125vb) (emphasis added): [Here follows the second part of the first part of this part: "For it is said in Romans 10:10, "We believe with the heart unto righteousness, but confess with the mouth unto salvation'." In the previous part there was discussion of those things which we must believe with the heart, namely, the articles of faith; now there remains an investigation of how we can faithfully confess with the mouth those things which we believe]. 
be: 'Here follows the second part [i.e. the De divinis nominibus] of the first part [i.e. the Commentary on the Nicene Creed] of this part [of the Summa]: Sicut enim dicitur ad Romanos [i.e. the De articulis fidei].' That gives us the following placement of the De divinis nominibus within the overall structure of the De articulis fidei:

De articulis fidei (Prima Pars of the Summa)

1. Part 1

i. Commentary on the Apostle's Creed

ii. De divinis nominibus

2. Part 2: Commentary on the Nicene Creed

3. Part 3: Commentary on the Athanasian Creed

Not only is this one possible reading of the incipit of the De divinis nominibus; it also potentially explains why John's Commentary on the Nicene Creed would have been appended to the De divinis nominibus in Trier 162. Whatever the case may be about John's intentions, it appears that the compiler of this manuscript or of its exemplar followed this interpretation of the incipit.

However, if we turn our attention to the distinction between what is believed with the heart and what is confessed in words, it becomes evident that the De divinis nominibus should not be appended to John's Commentary on the Apostle's Creed. When the De articulis fidei distinguishes between that which is believed with the heart and that which is confessed in words, it claims-somewhat counterintuitively -that all three of its credal commentaries fall under the heading of 'that which is believed with the heart'. Then, when the De divinis nominibus picks up the distinction, it agrees that a so-called 'previous part' has covered 'that which is believed with the heart', and promises that the De divinis nominibus will now take up 'that which is confessed in words'. This means that the De divinis nominibus places itself not in the midst of but after the three credal commentaries De articulis fidei. This leads us to a different interpretation of the structure of the De articulis fidei: what we traditionally think of as the De articulis fidei is only the prima pars of the De articulis fidei. The De divinis nominibus is its secunda pars:

De articulis fidei

1. Prima pars: What is believed in the heart

i. Commentary on the Apostle's Creed

ii. Commentary on the Nicene Creed

iii. Commentary on the Athanasian Creed

2. Secunda Pars (De divinis nominibus): What is confessed in words

The incipit to the De divinis nominibus can thus be interpreted in the following manner: 'Here follows the second part [i.e. the De divinis nominibus] of the first part of this part [of the Summa]: Sicut enim dicitur ad Romanos [i.e. the De articulis fidei].' This interpretation is to be preferred on the basis of internal evidence, as it makes 
the best sense of how these two texts frame themselves in relationship to one another. $^{24}$

As it stands, the text of the De divinis nominibus is unfinished, incompletely copied, or both. We can tell this by comparing the rest of the prologue to the work as a whole. After the reference to the De articulis fidei, the prologue continues with a taxonomy of the grammatical forms which our terms can assume when we speak about God. This taxonomy has been lifted almost verbatim from the Tractatus de divinis nominibus in the Summa of Praepositinus of Cremona. It differs from Praepositinus primarily in the addition of a distinction between abstract and concrete nouns, and by the omission of a taxonomy of adjectives. An outline of the taxonomy as it appears in John's De divinis nominibus is as follows; the names in parentheses are John's examples of each kind of name: ${ }^{25}$

\section{Vocabula about God}

1. Said from eternity (Deus, Bonus)

a. Befits all three persons (Iustitia)

i. $\quad$ Befits all three persons per se (Deus)

1. Abstract (Divinitas, Essentia)

2. Concrete (Deus)

ii. Befits none of the persons per se (Trinitas)

b. Befits only some of the persons

i. $\quad$ Befits two (Principium Spiritus Sancti, Vnare)

ii. Befits one (Pater, Filius, Spiritus Sanctus)

2. Said with reference to time (Creator, Refugium, Dominus)

24 While the simplest explanation should usually be preferred, another possibility is that the words istius partis from the incipit to the De divinis nominibus are a corruption of the words istius operis. This would require two assumptions. First, we would have to assume a paleographical error: at some point, a scribe forgot to copy the $o$ of $o p^{i s}$; a subsequent scribe saw $\underline{p}^{i s}$ and copied it as $p^{\text {tis }}$. Second, we would have to assume that John composed the prologue to the Summa as a whole after he composed both parts of the De articulis fidei, such that the incipit of the De articulis fidei at one point functioned as the incipit of the Summa as a whole. In that case, the interpretation of the prologue would be: 'Here follows the second part [i.e. the De divinis nominibus] of the first part [i.e. the De articulis fidei] of this work: Sicut enim dicitur ad Romanos [i.e. the Summa].' This reading makes for a clearer sentence, but it lacks manuscript evidence. It is also somewhat out of character with John's writing in the De divinis nominibus, which can be awkward at times, and tends to equivocate with the word pars.

25 John of La Rochelle, De divinis nominibus, prol. (Trier 162, fols 125vb-126ra). Since the manuscript has not been well-copied, it requires a great deal of editorial work. Where possible, I have corrected it from context, or from a comparison with its sources. All formatting is given by way of editorial suggestion. Letters or words that have been striken should be deleted; words in [brackets] should be added. I have also taken the liberty of standardizing orthography and punctuation. For the comparable text in Praepositinus, see Praepositinus of Cremona, Summa Qui producit ventos 1.1 (Angelini, 199). 
At the conclusion of the taxonomy, John promises to discuss each the members of the taxonomy in turn. But in reality, most of them are missing from the text as we have it. The text begins with two questions on whether and how we name God. ${ }^{26}$ After that, it takes up concrete and abstract nouns in the reverse order in which they are given in the taxonomy. The text breaks off in the middle of the discussion of abstract nouns. ${ }^{27}$ It never gets to the name Trinitas, or to any of the names that follow it.

\section{Question 1: Introducing the Analogy of Being}

Following the prologue, the first question begins with a proemium, announcing that anyone who wishes to discuss the divine names must begin with the question of whether God is namable at all. ${ }^{28}$ This seemingly innocuous observation is also a clue to how our author intends to engage the late $12^{\text {th }}$ - and early $13^{\text {th }}$-century tradition. Prior to William of Auxerre, it was generally assumed that God is namable, whether by equivocity or univocity, and so the subject matter of the traditional Tractatus de divinis nominibus was not whether, but how God is namable. But William innovated the tradition by beginning his own account of the divine names with a defense of our ability to know and to name God at all. ${ }^{29}$

William's defense of our ability to know and name God is grounded in the metaphysics of causality. Appealing to the impossibility of an infinite regress in causes, William argues that God can be known to exist as the uncaused cause, the source of influx into creatures, and the highest object of desire. ${ }^{30}$ For William, these metaphysical considerations protect the integrity of a grammatical approach to naming God. God, as the highest cause, so infinitely exceeds the natural world that any at-

26 John of La Rochelle, De divinis nominibus, qq. 1-2 (Trier 162, fol. 126ra-126vb).

27 The discussion of abstract nouns is divided into those which signify the divine nature without reference to creatures, and those which signify the divine nature with reference to creatures (Trier 162, fol. 130va). The discussion of those which signify the divine nature without reference to creatures is complete. The discussion of those which signify the divine nature with reference to creatures is subdivided into three names: Potentia, Sapientia, and Voluntas (Trier 162, fol. 133ra). After completing a discussion of Potentia, John divides the discussion of Sapientia into five parts: Scientia/Sapientia, Dispositio, Prouidentia, Predestinatio, Reprobatio (Trier 162, fol 138va). The subsequent text follows this outline, but breaks off on fol. 142rb in the middle of the dicussion of Prouidentia.

28 John of La Rochelle, De divinis nominibus, q. 1 (Trier 162, fol. 126ra): 'Volentibus tractare de diuinis nominibus a[o]ccuritur primo questio utrum Deus sit nominabilis et qualiter' [The first question that occurs to those who want to discuss the divine names is whether God is nameable, and how]. 29 On the centrality of this theme for William, see Valente, Logique et théologie, 266-7. William's Tractatus de divinis nominibus in the Summa Aurea includes a treatment of nomina essentialia (1. 1, tr. 4), nomina adiectiva (1. 1, tr. 5), and nomina personalia (1. 1, tr. 6). See William of Auxerre, Summa Aurea, vol. 1, ed. Jean Ribaillier (Paris: Editions du Centre National de la Recherche Scientifique (CNRS); Grottaferrata: Editiones Collegii S. Bonaventurae, 1980), 35-109. William's discussion of whether God is nameable can be found in Summa Aurea, 1. 1, tr. 4, c. 1 (Ribaillier, 36-40).

30 William of Auxerre, Summa Aurea, 1. 1, tr. 1, nn. 1-3 (Ribaillier, 21-2). 
tempt to carry signification gathered from Creation into our speech about the Creator necessarily fails. ${ }^{31}$ William thinks that a failure to appreciate God's apophatic transcendence in this way was actually the cause of the early Trinitarian heresies. ${ }^{32}$

When John takes up the question of whether we can know and name God, he begins by considering the negative opinion: 'That he cannot, is shown by threefold authority and reasoning. ${ }^{33}$ Bearing in mind the significance of William of Auxerre for the history of this question, if we compare this statement of John to the corresponding chapter of William's Summa Aurea, John appears to be describing precisely what one finds in William's text: obiectiones drawn from three specific auctoritates (Dionysius, Damascene, and [Pseudo-]Augustine), together with supporting reasoning. ${ }^{34}$ John then goes on to give verbatim many of the specific quotations which appear in the corresponding chapter of the Summa Aurea. ${ }^{35}$ Apart from a single, threeword reference to the Psalms in the fourth sed contra, ${ }^{36}$ John does not cite a single text that cannot be found in the corresponding chapter of the Summa Aurea.

The overlap between William's text and John's raises the question of which is prior. Apart from the fact that William's work is prior to John's in general, the fact that John's text is posterior also appears from a large section of text in the first obiectio, which is only present in John's text. It consists of a gloss on each of the words which Dionysius uses to deny that we can know and name God properly. The gloss aligns each of Dionysius' words with one member of a taxonomy of the apprehensive powers of the soul, and it aligns each apprehensive power of the soul with the kind of knowledge proper to it. ${ }^{37}$ The remote source of the taxonomy can be in-

31 William finds proof for this in the thirteenth chapter of John Damascene's De fide orthodoxa, which describes God as both 'incomprehensible' and 'above our thoughts'. See John Damascene, De fide orthodoxa 13.6, although William cites it as Chapter 10. For the text, see John Damascene, De fide orthodoxa: Versions of Burgundio and Cerbanus, ed. Eligius Buytaert (St. Bonaventure, NY: The Franciscan Institute, 1955), 59.

32 William of Auxerre, Summa Aurea, 1. 1, prol., s. 2 (Ribaillier, 18).

33 John of La Rochlle, De divinis nominibus, q. 1, proem. (Trier 162, fol. 126ra): 'Quod non, ostenditur auctoritate triplici et ratione.'

34 William of Auxerre, Summa Aurea, 1. 1, tr. 4, c. 1 (Ribaillier, 36-7).

35 John references the following texts:

Obj. 1 (Trier 162, fol. 126ra): Pseudo-Dionysius, De divinis nominibus 1.5 (Chevallier, 35). This is taken from William of Auxerre, Summa Aurea, 1. 1, tr. 4, c. 1, q. 1, obj. 3 (Ribaillier, 36).

Obj. 2 (Trier 162, fol. 126ra-b): John Damascene, De fide orthodoxa 1.13 (Buytaert, 59). This is taken from William of Auxerre, Summa Aurea, 1. 1, tr. 4, c. 1, q. 1, obj. 7 (Ribaillier, 37).

Obj. 3 (Trier 162, fol. 126rb): John does not actually cite any authentic texts of Augustine. He merely copies two texts which William attributes to Augustine. See William of Auxerre, Summa Aurea, 1. 1, tr. 4, c. 1, q. 1, obj. 7-8 (Ribaillier, 37).

36 John of La Rochelle, De divinis nominibus, q. 1, s.c. 5 (Trier 162, fol. 126rb): 'Item. In Psalmo: Dominus nomen illi' [Likewise. In Psalm [67:5 (Vulg.)]: The Lord is his name].

37 John of La Rochelle, De divinis nominibus, q. 1, obj. 1 (Trier 162, fol. 126ra): 'Prima est Dionysii in libro De diuinis nominibus. Deus omnibus per se uniuersaliter est incomprehensibilis, et neque sensus eius est (...) [neque fantasia], neque opinio, neque nomen, neque uerbum, neque tactus, 
ferred from the definition which John gives to the word, opinio. That definition reads est autem opinio acceptaio unius partis cum formidine alterius. It is based on Avicenna's De anima 5.1: opinio ( ... ) est conceptio ad quam accreditur cum formidine alterius partis. ${ }^{38}$ In that same paragraph, Avicenna goes on to give a very similar taxonomy of apprehensive powers and their acts as we find here. But as close as this parallel is, it is not an exact match to either of the two versions of Avicenna's De anima which were in circulation at the time. ${ }^{39}$ An even closer parallel can be found in John of La Rochelle's Tractatus de divisione multiplici potentiarum animae $2.23,{ }^{40}$ and his

[neque scientia,] et in enigmate, id est, in allegoria scripturarum. Ab omnibus dicit ut nullus homo excipiatur; universaliter ut omnis modus comprehendendi remoueatur. Quod tangit inductiue: neque sensus eius est etc.: Quedam comprehensio est per sensum, quedamsensitiua, que remouetur cum dicitur neque sensus eius est qua cognoscimus res corporales presentes. Quedam comprehensio est per ymaginationem siue fantasiam qua cognoscimus res corporales absentes, quod [que] remouetur cum dicitur neque fantasia. Quedam ap[com]prehensio est per rationem probabilem, que dicitur opinio (est autem opinio acceptatio unius partis cum formidine alterius); [que] removetur cum dicitur neque opinio est. Alia comprehensio est per doctrinam, et hoc dupliciter: nam alia est per scripturam; alia est per auditum. Illa que est per scriptum intelligitur per nomen; que per auditum intelligitur per uerbum. (...) Alia ap[com]prehensio [est] interior, et hoc est duplex: quí[e]dam enim est affectus, et ita comprehensio est sicut tactus, sicut patet in amore, que est copula amantis et amati, sicut dicit Augustinus; alia est intellectus, et ista dicitur scientia' [The first comes from Dionysius in the book, On the Divine Names. God is incomprehensible of himself universally to everyone and there is no sense of him (...) [nor phantasm], nor opinion, nor name, nor word, nor touch, [nor knowledge] and in a mystery, that is, in biblical allegory. By everyone he says that no person is excluded; universally that every manner of comprehending is removed. He discusses this inductively: there is no sense of him, etc.: There is a certain comprehension by sense, which is removed when it is said there is no sense of him by which we know present, corporeal things. There is a certain comprehension by imagination or phantasm, by which we know absent corporeal things, which is removed when it is said nor phantasm. There is a certain comprehension by probable reason, which is called opinion (now, opinion is the acceptance of one possibility with apprehension about the other); this is removed when it is said nor is there opinion. Another comprehension is by teaching, and this happens in two ways: for one [kind of teaching] is by writing; the other by hearing. The one which is by writing is intended by name; the one which is by hearing is intended by word. (...) Another comprehension [is] interior, and this is twofold: one is the affect, and in this way comprehension is like touch, as takes place in love, which is the union of the love and the beloved, as Augustine says; the other is the intellect, and in this way it is called knowledge].

38 Avicenna, De anima 5.1. The text can be found in Avicenna Latinus, Liber de anima seu Sextus de naturalibus, vol. 2, ed. S. van Riet (Louvain: Peeters; Leiden: Brill, 1972), 79: [Opinion (...) is a conception which one trusts with apprehension about another possibility].

39 On the two Latin versions of Avicenna's De anima see Dag Nikolaus Hasse, Avicenna's De anima in the Latin West: The Formation of a Peripatetic Philosophy of the Soul, 1160-1300 (London: The Warburg Institute, 2000), 7-8; on the availability of both to John, see Hasse, Avicenna's De anima, 50. Simone van Riet, 'Le “De anima” d'Avicenne: Une conception spiritualiste de l'homme,' in Avicenna Latinus, Liber de anima, $94^{\star}-6^{\star}$, points out that while the two versions agree concerning the definition of opinio, ten manuscripts of Version A and one manuscript of Version B contain a gloss on the definition of opinio, which distinguishes it from dubitatio.

40 John of La Rochelle, Tractatus de divisione multiplici potentiarum animae 2.23, ed. Pierre MichaudQuantin (Paris: J. Vrin, 1964), 97. 
Summa de anima $119 . .^{41}$ In those respective chapters, John is paraphrasing the section of Avicenna just referenced. He gives verbatim the definition of opinio that we find in our text, but develops the material we find in the De divinis nominibus significantly further. It seems reasonable to infer, therefore, that in the De divinis nominibus John is working from a copy of William's Summa Aurea, ${ }^{42}$ and that he has added this taxonomy to it. He appears to have done so in an initial effort to incorporate some of the distinctions about the soul which he found in Avicenna, and which he would further develop in subsequent work.

Although John does, for the most part, stay close to William's ideas, and even to William's wording, there are two other places in this question where John makes major revisions to William's work. The purpose of these revisions appears to have been to introduce William's discussion of the metaphysics of causality-which was originally supposed to deny the possibility of naming God proprie from creaturesinto the traditional Tractatus de divinis nominibus in such a way as to make it the basis upon which we name God proprie from creatures. We see evidence of this shift in a large deletion from the solutio, and an addition in the reply to the third sed contra. The deleted section from the solutio contains a statement from William, together with auctoritates and rationes, to the effect that we cannot name God proprie. ${ }^{43}$ This may have been a common theme throughout the late $12^{\text {th }}$ and early $13^{\text {th }}$ centuries, but John's introduction of the metaphysics of causality into the Tractatus de divinis nominibus would ultimately call it into question.

With the ground thus cleared to make a more radical change, the reply to the third sed contra begins the work of doing so. In the passage of the Summa Aurea parallel to it, William clarifies that when we say ens of God, we intend something purely negative. We start with the ens which is known first to the intellect; we add the privation non ab alio; and the resultant name means something like 'unreceived-being'

41 John of La Rochelle, Summa de anima 119, in Summa de anima: Texte critique avec introduction, notes, et tables, ed. Jacques Guy Bougerol (Paris: J. Vrin, 1995), 285.

42 The use of William of Auxerre in this way was common in the 1230s. Doucet, 'Prolegomena,' cxxxI, points to the fact that both Hugh of St Cher in the composition of his Commentary on the Sentences, as well as Roland of Cremona in the composition of his Summa, had William's Summa Aurea 'constanter prae oculis'. Magdalena Bieniak, 'The Sentences Commentary of Hugh of St Cher,' in $M e$ diaeval Commentaries on the Sentences of Peter Lombard, vol. 2, ed. Philipp W. Rosemann (Leiden: Brill, 2009), 134, confirmed this initially with regard to Book 1 of Hugh of St Cher's Commentary on the Sentences, and subsequently with regard to the work as a whole in Magdalena Bieniak, The Soul-Body Problem at Paris ca. 1200-1250 (Leuven: Leuven University Press, 2010), 100: 'A substantial part of Hugh of St Cher's Sentences Commentary consists in an almost verbatim reproduction of William of Auxerre's Summa aurea.' Riccardo Quinto, 'Le commentaire des Sentences d'Hugues de Saint-Cher et la littérature théologique de son temps,' in Hugues de Saint-Cher (d. 1263): bibliste et théologien, ed. Louis-Jacques Bataillon, Gilbert Dahan, and Pierre-Marie Gy (Turnhout: Brepols, 2004), 315, n. 41, makes a similar claim about Roland of Cremona's Summa, arguing that commonalities between Hugh and Roland can most likely be explained by their common use of William of Auxerre's Summa Aurea.

43 William of Auxerre, Summa Aurea, 1. 1, tr. 4, c. 1, q. 1, sol. (Ribaillier, 39). 
(literally, ens non ab alio) or that which is 'truly being' (vere ens). ${ }^{44}$ For William, even vere ens is radically negative; it becomes a proper name for God only by losing its previous connection with the creatures it used to signify. ${ }^{45}$ William thinks that this is part of God's providential plan for our salvation. Quoting Ps. 17:12 (Vulgate) in the reply to the first sed contra, that God 'conceals himself in darkness', William argues that God hides from natural reason 'so that faith may be meritorious' ${ }^{46}$

John changes the structure of William's negative predication. 'Positive knowledge' (cognitio positiva), he says, is knowledge which is like 'sight' (uisus) and 'absolute' (absoluta). No Christian theologian, save perhaps for the ontologists of the $18^{\text {th }}$ century, would argue that humanity can have this kind of sight in uia. But between William's absolutely negative knowledge and the vision of the saints in heaven, John makes room for an analogy based on the metaphysics of causality: since the soul knows that God is the cause of its being, it also knows that God possesses being 'better' (melius) and more 'nobly' (nobilius) than the soul does. There is thus opened through the via negationis and the via causalitatis by which the soul knows itself, a kind of via eminentiae, whereby it predicates being of God in connection with, not in contrast to, its own being. ${ }^{47}$ Moreover, since according to this line of reason-

44 William of Auxerre, Summa Aurea, 1. 1, tr. 4, c. 2, sol. (Ribaillier, 42-3).

45 Valente, Logique et théologie, 267-72, notes that William does in a certain respect attempt to make room for the univocal tradition. Although conceding that theological terms are, properly speaking, equivocal with their philosophical homographs, William does admit that they are univocal with reference to their effects. His example is 'justice'. Although created justice and uncreated justice are equivocal in themselves, they agree in their principal effect: giving to each his due. See William of Auxerre, Summa Aurea, 1. 1, tr. 5, c. 3 (Ribaillier, 72-3). Although preserving a preference for equivocity, expressed in similar language, in the case of nomina essentialia, William does admit certain other forms of univocity in tr. 6, c. 2 (Ribaillier, 83).

Philip the Chancellor largely follows William on this point. See Philip the Chancellor, Summa de bono, prol., q. 4, vol. 1, ed. Nicolai Wicki (Bern: Francke, 1985), 21. While preserving the fundamentally negative character of the term bonum as applied to God, he sees a certain correspondence between the effects of uncreated and created goodness, which he describes as a proportio.

46 William of Auxerre, Summa Aurea, 1. 1, tr. 4, c. 2, ad s.c. 1 (Ribaillier, 40): 'Deus enim modo se occultat nobis et ponit tenebras latibulum suum ut fides habeat meritum' [God hides himself from us now and conceals himself in darkness [Ps. 17:12 (Vulg.)] so that faith may have merit].

47 John of La Rochelle, De divinis nominibus, q. 1, ad s.c. 3 (Trier 162, fol. 126va): 'Ad illud Damasceni, quod cognitio Dei naturaliter est insita anime, distinguendus est cognitio priuatiua siue comparationis, et sic naturaliter Deus cognoscitur ab anima rationali. Cognoscit enim rationalis creatura quia non fuit semper, et ita quod ex nichilo in esse. Quare et ab alio est, quod conuertit non esse tale quale ipsum est, sed melius et nobilius. Et est cognitio positiua, que est sicut uisus et absoluta. Et sic Deus ab anima non cogitatur in uia' [To the objection from Damascene, that the knowledge of God is naturally placed within the soul, we should distinguish privative knowledge or [knowledge] by comparison. According to this sort of knowledge, God is naturally known by the rational soul. For a rational creature knows that it did not always exist, and thus that it was brought forth from nothing into being. Wherefore it comes from another, which converted the non-being [into being], only [that other] is better and more noble [than itself]. There is also positive knowledge, which is like sight and 
ing, the soul does not approach God altogether in darkness, John substitutes William's citation from the Psalms in the reply to the first sed contra with a citation from 1 Timothy more to his purpose: it is not that God dwells in darkness, so much as God 'reclines in inaccessible light'. ${ }^{48}$

\section{Question 2: Relating the Analogy of Being to the Previous Tradition}

John refines his use of the analogy of being in his reception of the next question in William's work: on Dionysius' distinction between symbolic and mystical theology. ${ }^{49}$ For William, the distinction has to do with the origin of the words with which we name God. If the words come from creatures outside the soul, they are symbolic; he gives the examples of 'lion' and 'fire'. If the words come from effects that God creates inside the soul in the midst of prayer and contemplation, they are mystical; he gives the examples of 'sweet' and 'beloved'. William is clear that there is no fundamental difference between how the words are used once they are taken from their respective spheres: both categories of words signify creatures, and so both are predicated of God by way of negation..$^{50}$

On the surface, John seems to accept William's use of Dionysius' distinction between symbolic and mystical theology: he copies William's association of symbolic theology with exterior creatures and his association of mystical theology with 'interior' creatures..$^{51}$ But he also revises William's text to make room for an analogy based on the metaphysics of causality alongside the other two ways of naming God. He does so with reference to a quotation from Damascene that John borrows from the next question in William's work. The context of that quotation is a discussion of the apparent disagreement between Damascene and Dionysius about whether Qui est or bonum is the first name for God..52 John will take up that discussion later in

is absolute. God is not known by the soul in this way in via]. In Summa de anima 18 (Bougerol, 74), John introduces a similar point in the context of arguing that the soul is not caused by an angel. 48 John of La Rochelle, De divinis nominibus, q. 1, ad s.c. 1 (Trier 162, fol. 126va). 'Non enim se habet oculus interior intellectus ad lucem summam que est Deus sicut oculus exerior ad lucem corporalem. Comparatio enim ex parte illa est finiti ad infinitum. Ex parte alia finiti ad finitum. Et ideo deficit intellectus in contemplatione. Recumberatur enim a luce inaccessibili' [The interior eye of the intellect is not oriented towards the highest light, which God is, like the exterior eye is to corporeal light. For the former comparison is of the finite to the infinite; the latter comparison is of one finite thing to another. This is the reason why the intellect fails in contemplation: he dwells in inaccessible light]. 49 In his edition of the Summa Aurea, 1. 1, tr. 4, c. 1 (Ribaillier, 40 -1), Ribaillier does not distinguish this as a second question, but the text raises a separate topic and offers a separate solutio, and for this reason ought to be distinguished as a separate question.

50 William of Auxerre, Summa Aurea, 1. 1, tr. 4, c. 1, q. 2, sol. (Ribaillier, 40-1).

51 John of La Rochelle, De divinis nominibus, q. 2 (Trier 162, fol. 126va-b).

52 William of Auxerre, Summa Aurea, 1. 1, tr. 4, c. 2 (Ribaillier, 41-3). 
Question 4, and so we will have reason to return to it below. But in order to establish the context for John's quotation here, we may note that one of William's objectors argues that since all names are equivocal when predicated of God, there is no way to establish which is first:

Every name by which we name God names him through an image which is from our perspective (secundum nos). Therefore, both the name "he who is" (Qui est) and the name "good" (bonum) name God through an image which is from our perspective. Therefore, since no image drawn from creatures necessarily occurs first, seeing as we can use any of them indifferently, it follows that neither of those names comes first in God. ${ }^{53}$

In support of this objection, William's objector quotes a colorful passage from Damascene:

It is impossible for us human beings, clothed with our thick flesh, to understand and to speak of the divine and non-material workings of God, unless we use images, forms, and signs, which are from our perspective (secundum nos). ${ }^{54}$

Although William does not agree with the objector in general, since he thinks that ens names God simpliciter, while bonum also connotes an effect in a creature, ${ }^{55}$ William himself uses this quote to reinforce a point which he will later affirm: for an image, form, or sign to be secundum nos is for it to be said translative of God. Even when we use a name like ens which signifies the divine essence proprie, 'we do not understand God in that [predication] without some sign or distinction, since the privation itself is a sort of sign or distinction. ${ }^{56}$ This means that although we use a word that describes God proprie, we can only use it translative.

John takes up William's quotation from Damascene into the solutio of his second question, in order to refine the relationship between the analogy of being and the previous tradition. Taking advantage of the fact that Damascene gives three examples of things we use to speak of God, John adds a third member to Dionysius' distinction between symbolic and mystical theology, and to William's related distinction between naming God from exterior effects and naming God from interior effects:

53 William of Auxerre, Summa Aurea, 1. 1, tr. 4, c. 3, obj. 2 (Ribaillier, 41-2): “[O]mne nomen quo nominamus Deum nominat ipsum per ymaginem que est secundum nos. Ergo et hoc nomen "qui est” et hoc nomen "bonum" nominant Deum per ymaginem que est secundum nos. Ergo cum nulla ymago creaturarum ex necessitate primo occurrat, quia qualibet possumus uti indifferenter, sequitur quod nullum illorum nominum sit principalius in Deo.'

54 John Damascence, De fide orthodoxa 11 (Buytaert, 52), quoted in William of Auxerre, Summa Aurea, 1. 1, tr. 4, c. 3, obj. 2 (Ribaillier, 41): 'Homines grossam hanc carnem <indutos>, divinas non $<$ materiales> operationes deitatis intelligere et dicere impossibile est, nisi ymaginibus et formis et notis que sunt secundum nos usi fuerimus.' I have given the text as it appears in William's work. 55 William of Auxerre, Summa Aurea, 1. 1, tr. 4, c. 2, sol. (Ribaillier, 42).

56 William of Auxerre, Summa Aurea, 1. 1, tr. 4, c. 2, sol. (Ribaillier, 43): '[N]on intelligitur ibi Deus sine nota vel distinctione aliqua, quia ipsa privatio est quasi quedam nota sive distinctio.' 
Therefore, God is named in three ways, by images of material things; by forms of spiritual things; [and] by signs of privations, all of which are from our perspective (secundum nos). Therefore, God is named in three ways: from a property of a material thing, as in "lion", "sun"; from a property of a spiritual thing, as in "wise", "benevolent"; [and] by a privative distinction or sign, as in "uncreated", "immense". ${ }^{57}$

What John says concerning ymagines corresponds with William's description of symbolic theology. What John says concerning formae corresponds with William's description of mystical theology. But the words that John uses to describe our use of signa, which he takes out of context from William's explanation of how we can speak words that refer to God proprie, suggest that John is attempting to move beyond William here. William and John agree that speaking in this way includes a privation. For William, this was supposed to preserve the apophatic character of our speech about God. But since for John, the language of privation includes the analogy of being, the addition of a third member to Dionysius' distinction appears to be a deliberate attempt to make room within the previous tradition for the possibility of using the analogy of being to name God proprie. John explores this possibility further in the subsequent question.

\section{Question 3: Refining the Analogy of Being}

John's third question tries to reconcile the earlier tradition with the analogy of being that he had introduced in Questions 1-2. That John is-at least in his own mindcharting new territory with his third question is clear from the question's structure and content. Without William's auctoritates and rationes to rely upon, it is dramatically shorter. It consists of two obiectiones, two sed contra, and replies to each. There is no separate solutio. The tenuousness of John's response is reflected in the qualified manner in which he offers it: sine preiudicio. ${ }^{58}$ In the reply to the first sed contra, John gives an initial description of how he thinks the analogy of being works. Bearing in mind that John thinks that the name ens includes the privation non ab alio, he uses this text to connect the via negationis with the via causalitatis.

Ens or esse is said per prius and posterius of God and a creature because he is the fount and origin of being in creatures. Therefore he truly "is" immutably and per se, while being is said

57 John of La Rochelle, De divinis nominibus, q. 2 (Trier 162, fol. 126vb): 'Tripliciter ergo nominatur Deus, "que sunt secundum nos": ymaginibus corporum; formis rerum spiritualium; [notis] priuationum. Tripliciter ergo nominatur Deus: proprietate rei corporalis ut Leo, Sol; proprietate rei spiritualis ut Sapiens, Benignus; distinctione priuatiua siue [nota] ut Increatus, Immensus.'

58 John of La Rochelle, De divinis nominibus, q. 3, sol. (Trier 162, fol. 126vb): 'Ad hoc responderi potest sine preiudicio' [We can respond to this without prejudice]. 
per posterius of a creature, both because it "is" per accidens, and because it "is" secundum quid. ${ }^{59}$

The reference to immutability suggests that our author intends that the via eminentiae should follow upon the via causalitatis. He draws this out more explicitly in his reply to the second objection.

With regard to the second we should say that when I say "he who is" (qui est), it names God properly, because he is being most fully. Three things need to be taken into account:

The first is that the thing signified (res significata) by my saying qui est is superior to every description, which is shown in the circumlocution by which qui est tries to describe it. It appears that our language fails in the concrete when it narrates what it names with a circumlocution.

The second is that it is an infinite res, which is made clear by the infinite name, qui est.

Moreover, the third is that he "is" truly and immutably, which is shown in the co-signification of the verb est. For the present tense co-signifies. Augustine in Eighty-Three Questions [q. 17] argues thus: Everything past no [longer] exists. [Everything] future does not yet exist. Therefore also, there is no (...) past and future, that is, in God. It is clear from this that immutability is understood in the co-signification of the present. From these [arguments] it is clear that that when I say qui est, it signifies the divine essence proprie, not translative.

But here we should note: that you do not fully describe the being of any creature if you say qui est, unless you say qui est hoc, like qui est anima, or angelus, or celum, or terra, or things of this sort. ${ }^{60}$

59 John of La Rochelle, De divinis nominibus, q. 3, ad 1 (Trier 162, fol. 126vb): 'Ens uel esse dicitur per prius et posterius de Deo et creatura quia ipse est in creatura fons et origo essendi. Et ideo uere est immutabiliter et per se. Esse uero per posterius dicitur de creatura et quia per accidens et secundum quid.' A similar idea about priority and posteriority appears in Philip the Chancellor, Summa de bono, prol., q. 5 (Wicki, 23), but Philip's understanding of priority and posteriority still follows William on equivocity and univocity.

60 John of La Rochelle, De divinis nominibus, q. 3, ad 2 (Trier 162, fol. 127ra): 'Ad secundum dicendum quod propri[e]ts nominat Deum hoc [quod] dico qui est, quoniam ens e[s]t plenius. Tria enim notantitus[ur]:

Primum est quod res significata per hoc quod dico qui est superior est omni narratione, quod monstratur in circumlocutione qua pretendit qui est. In concreto apparet quod deficit lingua in illius narratione quod circumlocutione nominatur.

Secundum est quod sit res infinita, quod monstratur per nomen infinitum, qui est.

Tertium est eiam quod uere et immutabiliter est, quod monstratur in consignificatione huius uerbi est. Presens enim consignificat. Augustinus in libro Octoginta III Questionum [q. 17] argumentatur sic: Omne praeteritum (...) non est. [Omne] futurum nondum est. Ergo eciam, omne (...) pretertium et futurum deest, scilicet, apud Deum. Ex quo patet quia immutabilitas intelligitur in consignificatione presentis. Ex hiis manifestum est quoniam hoc quod dico qui est proprie, non translatiue, diuinam essentiam significat. Est hic tamen notandum, quod de nulla creatura plene describis esse si dicas $q u[i]$ est, nisi dicas, $q u[i]$ est hoc, ut qu[ima, uel angelus, uel celum, uel terra, et huiusmodi.' 
Here John carefully aligns the via eminentiae with the via causalitatis, through an appeal to the infinity of the divine being. This would seem at odds with the idea that the analogy of being should merely complement the earlier tradition, as John had suggested in Question 2, were it not for the fact that John is also very careful about the way in which he employs the via eminentiae. Although he does not do so as explicitly as he might, John introduces here a distinction between the res significata and the modus significandi in the via eminentiae which he uses to preserve most of the substance of the earlier tradition. ${ }^{61}$

To be fair, John's use of the res / modus distinction is inchoate and not as explicit as it might be; while res significata functions as a technical term here, modus significandi does not. That he intends 'abstract' and 'concrete' as modi significandi has to be inferred the language of the prologue, which uses the term modus to refer to the abstract and concrete use of names. But once we make the connection, it becomes clear that John tries to incorporate the earlier, apophatic tradition into the via eminentiae by adhering to the concrete modus significandi, while detaching the res significata from any reference to creatures. This allows him to establish a connection between words formed among the human disciplines and the names we use for God, while preserving the earlier tradition's insistence that the signification of those words cannot be carried over into our speech about God.

\section{Question 4: Rejoining the Earlier Tradition}

Having introduced the res / modus distinction as a means of harmonizing the earlier tradition with the analogy of being, John is now able to rejoin William's text and to explain the ordering of the divine names. His adherence to the concrete modus significandi and his detachment of the res significata from any reference to creatures allow him to repeat what William says verbatim, even if underneath the surface a great deal has changed:

Yet, we should note this: that the name qui est names God by a simpler ratio than the name bonum. For it is ens which first presents itself to the intellect. But when you add the privation "unreceived" (non ab alio), it becomes a proper name for God. And in this way it signifies

61 The distinction being employed here has received a significant amount of scholarly attention in recent decades. For bibliographies on its history, see Valente, Logique et théologie, 47, n. 38, and Gregory Rocca, Speaking the Incomprehensible God: Thomas Aquinas on the Interplay of Positive and Negative Theology (Washington, DC: The Catholic University of America Press, 2012), 335, n. 6. Irène Rosier, 'Res significata et modus significandi: Les implications d'une distinction médiévale,' in Sprachtheorien in Spätantike und Mittelalter, ed. Sten Ebbesen (Tübingen: Gunter Narr Verlag, 1995), 143, observes that Alan of Lille employed the same distinction with regard to the name Qui est, but thought that since our speech does not preserve the ratio significandi, it is all improper. This may suggest an additional reason for John's tenuousness: he is not only parting company with William of Auxerre, he is even calling into question Alan of Lille. 
God without any image drawn from a creature. It is an oblique name, according to which a privative distinction is understood, that is, unreceived being (ens non per aliud). But the name bonum goes beyond the ratio of my saying qui est. For it connotes an effect in a creature, namely, the love or rest by which a rational creature reaches its end in God and rests in him as in its end. ${ }^{62}$

The rationes of qui est and bonum, as well as the ordering between them, are taken directly from William. ${ }^{63}$ Yet there is one important difference between John and William here. For William, we can know more than we say; we can use names that name God proprie in themselves, but we always use them translative. This means that our knowledge of God can extend beyond creatures, but our speech about God is always in some way tied to them. It is otherwise for John. We can use concrete names that signify God proprie in themselves, and we can even use those names proprie, but only if we first abandon the connection between their signification and creatures. Consequently, when William says in the course of his argument that 'although the name qui est is not said translative of God, nevertheless we do not understand God through it without an image, or sign, or note from a creature, ${ }^{64}$ John has to delete this phrase. On the surface, he does so for the sake of consistency. Since it was an allusion to Damascene's comment about our 'thick flesh', which John had earlier re-interpreted to refer to the analogy of being, John would have effectively said that God can be understood without the analogy of being had he left the phrase in, which is precisely the opposite of what he was at pains to show. But under the surface, and more importantly, he had to delete it because detaching our signification from creatures was the only way in which John could harmonize the earlier tradition with the analogy of being. The name Qui est names God proprie in itself and we name God proprie with it when we use it, but only at the expense of our knowing precisely what we mean to say when we do.

\footnotetext{
62 John of La Rochelle, De divinis nominibus, q. 4, sol. (Trier 162, fol. 127rb): 'Hoc tamen notandum, quoniam hoc nomen qui est simpliciori ratione nominat Deum, quam hoc nomen bonum. Ens enim est quod primo se offert intellectui. Addita tamen hac priuatione, non ab alio, efficitur proprium nomen Dei. Et ideo significat Deum sine aliqua ymagine creature conuocata. Nomen obliquum [est], secundum quod intelligitur distinctio priuatiua, id est, ens non per aliud. Hoc uero nomen bonum superhabundat restut [rationem] huius quod dico qui est. Conuocat enim effectum in creatura, scilicet, dilectionem uel quietem qua creatura rationalis finitur in Deo et quiescit sicut in fine suo.'

63 William of Auxerre, Summa Aurea, 1. 1, tr. 4, c. 2, sol. (Ribaillier, 42-3).

64 William of Auxerre, Summa Aurea, 1. 1, tr. 4, c. 2, sol. (Ribaillier, 43): 'Vel potest dici quod, quamvis hoc nomen 'qui est' non dicatur translative de Deo, tamen non intelligimus Deum per ipsum sine ymagine vel signo vel nota creaturae' [Or it can be said that although the name 'He who is' is not said translative of God, nevertheless we do not understand God by it without an image, or form, or sign of a creature].
} 


\section{Relationship to the Summa Halensis}

Given the incomplete state of the De divinis nominibus, we must exercise caution before speaking of this text as a potential 'source' for the Tractatus de divinis nominibus of the Summa Halensis. ${ }^{65}$ To speak of it as a source would seem to imply that it existed as a published work and that the editor of the Summa Halensis had the work on his desk or in his mind when composing the corresponding sections of the Summa Halensis. That may be too much to ask of a text that never reached the stage of formal publication. However, the state of the text does not preclude us from examining its relationship to the Summa Halensis altogether. That is because the best available evidence suggests that that John himself was not only the author of the De divinis nominibus studied above, but also the editor, or at least the principal editor, ${ }^{66}$ of the corresponding section of the Summa Halensis. We might therefore more profitably ask whether or to what extent these two works might be representative of John's thought at different stages of his career. In this respect, the De divinis nominibus can serve as a reference point, which establishes the tradition within which and the trajectory along which John developed his understanding of the analogy of being in the Summa Halensis.

While any definitive discussion of this possibility would require a more in-depth study than space will allow us here, in what remains I will attempt to show what that trajectory might look like: in the De divinis nominibus, John introduces the analogy of being alongside the earlier tradition, by adhering to the concrete modus significandi but detaching the res significata from any reference to creatures. In the Summa Halensis, he develops his thought in two ways. First, he allows this synthesis from his earlier work to stand in for the earlier tradition, recategorizing names spoken of God in this way as nomina negativa. Second, he introduces another, radically kataphatic manner of knowing and naming God alongside it: that of denying the concrete modus significandi while affirming the res significata drawn from creatures. It is this newer way of knowing and naming God that he now assigns to the via eminentiae.

We can see how the Summa Halensis begins to relate to John's earlier work by examining its use of Damascene's colorful statement about our 'thick flesh'. William had merely used the text as an illustration that all of our words fail in the predication of God, while John initially took it as an occasion to introduce the analogy of being into the traditional Tractatus de divinis nominibus by associating Damascene's images, forms, and signs, with symbolic theology, mystical theology, and the analogy

65 The Tractatus De divinis nominibus can be found in Alexander of Hales, Doctoris irrefragabilis Alexandri de Hales Ordinis minorum Summa theologica (SH), 4 vols (Quaracchi: Collegium S. Bonaventurae, 1924-48), Vol I, P2 (nn. 333-518), pp. 491-751. The part corresponding to qq. 1-4 of John’s De divinis nominibus can be found in $S H$ I, P2 (nn. 333-52), pp. 491-523.

66 Doucet, 'Prolegomena,' CCCLXII-CCCLXV. 
of being respectively. The Summa Halensis quotes this same passage from Damascene in the question of whether the divine being can be named with a name of essence. Although there have been significant developments in the period between the De divinis nominibus and the Summa Halensis, the outlines of John's earlier thought are still clearly discernible:

\begin{abstract}
We should say that naming the divine esse happens in two ways: by its effects and by impressions of notions placed into the intellect. By effects he is named Creator, Omnipotent, and even God, as will be made clear. But by impressions of notions, which are placed into the intellect, he is named being, true, and good: for these notions of first being, first truth, and first good, have been impressed on us, as was said above, in the Question about Divine Essentiality, and the Question of Goodness. Now, the notion of being is first, because being is the first intelligible, wherefore with this notion impressed upon it from the divine being, as Damascene says that "the knowledge of God's being has naturally been placed in us", it [i.e. the soul] names God ens and essentiam, and this takes place from our perspective (secundum nos). ${ }^{67}$
\end{abstract}

The Summa Halensis tracks John's earlier work closely. It begins with the notion of being; it attributes that notion to the soul apart from external creatures; and the soul applies that notion to God by a via negationis (because it receives it from another), a via causalitas (because God is its cause), and a via eminentiae (because God possesses it pre-eminently). Apart from the epistemology of impressed concepts, which explains how the knowledge of being arrives in the soul, as well as the ratio of true, which by this point has made its way into the discussion, ${ }^{68}$ this teaching on analogy in the Summa Halensis is almost exactly what we found in John's earlier work.

Making an allowance for the developments just mentioned, there is only one major difference between the doctrine of analogy in the Summa Halensis and John's earlier work: the Summa Halensis argues that the analogy of being, conceived in this way, should not only stand alongside, but in some respects replace the earlier tradition. Let us recall that in the interpretation of Damascene's comment about our 'thick flesh', John's earlier work associated symbolic theology with ymagines drawn from God's corporeal effects, mystical theology with signa drawn from God's intelli-

\footnotetext{
67 SH I, P2, In2, Tr1, Q1, M1, C1, Ar1 (n. 345), Solutio, p. 513: 'Et dicendum quod nominatio divini esse est duobus modis: per effectus et per impressiones notionum quae sunt inditae intellectui. Per effectus nominatur Creator, Omnipotens et etiam Deus, sicut patebit. Per impressiones vero notionum quae sunt inditae intellectui nominatur ens, verum et bonum: hae enim notiones entis primi et veri primi et boni primi nobis impressae sunt, ut declaratum est supra, Quaestione de divina essentialitate et Quaestione de bonitate. Notio autem entis prima est, quia ens est primum intelligibile: unde hac notione sibi impressa de divino esse, sicut dicit Damascenus quod "cognitio essendi Deum naturaliter nobis inserta est”, nominat Deum ens et essentiam, et hoc secundum nos.'

68 A likely source for the inclusion of this name in John's subsequent work is Philip the Chancellor's Summa de bono. Philip begins the Summa de bono by taking up William's question about the comparison of ens and bonum in q. 1 (Wicki, 8-9), but then proceeds to insert a consideration of verum into that discussion in qq. 2-3 (Wicki, 9-20).
} 
gible effects, and the analogy of being with nota made from privations. The Summa Halensis does something even more bold. By arguing that the analogy of being begins with impressed concepts, which are-after all-intelligible effects, the Summa Halensis simply replaces William's mystical theology with the analogy of being. Accordingly, it reinterprets Damascene in such a way as to definitively rewrite the earlier tradition: it associates the analogy of being with formae drawn from God's intelligible effects, rather than notae of privations.

Therefore, with regard to the objection from John Damsascene, the response is already clear, because we name God with a name of essence: both with a form, that is, with a notion placed within us, and also from our perspective (secundum nos). ${ }^{69}$

As John had done in the De divinis nominibus, the editor of the Summa Halensis betrays a hint of caution as he steps out beyond the received tradition. Responding to the second objection, which argued from Rom. 1:20 that the invisibilia of God are made know through ea quae facta sunt, and not in any other way, and that ea quae facta sunt refers only to corporeal creatures, the Summa Halensis responds:

We should say that the Apostle says that divinity is understood "through those things which
have been made", yet he does not deny that it can be known through impressed notions. Never-
theless, even if it were said that it is not possible to understand divinity except through that
which has been made, then in that case, notions placed in [the soul] to know God should be
counted among those "things which have been made", as means to understanding and naming
God $(. . .)^{70}$

One can sense a certain anxiety here. The editor is defensive, seemingly aware of how significant a step he is taking.

It is not that the Summa Halensis altogether abandons the earlier tradition, even if it seems to be replacing it with the analogy of being. The editor simply seems to consider John's earlier idea of adhering to the concrete modus significandi and detaching the res significata from any reference to creatures as a sufficient way of safeguarding the apophatic concerns of that earlier tradition. He therefore no longer feels the need to place this kind of analogy alongside the earlier tradition. Accordingly, he

69 SH I, P2, In2, Tr1, Q1, M1, C1, Ar1 (n. 345), Ad obiecta 1, p. 513: 'Ad illud ergo quod obiecitur a Ioanne Damasceno iam patet responsio, quia nomine essentiae nominamus Deum et forma, hoc est notione nobis indita, et etiam secundum nos.' See Rosier, 'Res significata et modus significandi,' 147.

70 SH I, P2, In2, Tr1, Q1, M1, C1, Ar1 (n. 345), Ad obiecta 2, p. 513: ‘[D]icendum quod Apostolus dicit quod divinitas intelligitur "per ea quae facta sunt", non tamen negat quin possit intelligi per notiones impressas. Et tamen si diceretur quod non est possibile aliter intelligere divinitatem nisi per illud quod factum est, tunc notiones insertae ad cognoscendum Deum deputarentur in is "quae facta sunt" sicut media ad intelligendum et nominandum Deum; notio tamen entis sive essentiae absolvit ab omni comparatione.' 
reclassifies names that are said in this way as nomina negativa. ${ }^{71}$ He goes on to describe these names as names which proceed from effect to cause, in such a way 'they are said proprie in one sense, and improprie in another sense' ${ }^{72} \mathrm{He}$ is even willing to say that they are used per translationem, ${ }^{73}$ though he continues to maintain that they are said proprie without reference to creatures. ${ }^{74}$

Alongside these nomina negativa, the editor makes room for a new kind of name: one which utilizes the res / modus distinction in the opposite way, denying the concrete modus significandi, but affirming the res significata drawn from creatures. John describes names that follow this pattern as those which proceed from cause to effect in such a way that:

[The soul] more truly attributes those names, which signify a species without matter or a perfection of nature, to the cause rather than to its effects. Wherefore according to this way, goodness, truth, and things of this sort are said to be in God, and much more proprie than [they are said] of a creature, because goodness, truth, and power are in God by essence, but in a creature by participation. $^{75}$

With its negative names, the Summa Halensis preserves the earlier tradition by means of John's analogy of being from the De divinis nominibus. But with its names of eminence, the Summa Halensis develops and moves beyond the earlier tradition, including John's De divinis nominibus, by arguing that there are names formed among the human disciplines which can carry their signification over into our knowing and naming God, even when we name God proprie.

\section{Conclusion}

As mentioned at the outset of this essay, the Summa Halensis was part of a broader movement towards analogy in the mid $13^{\text {th }}$ century. Assuming that the editor of its Tractatus de divinis nominibus is one and the same as the author of the De divinis nominibus of Trier 162, it would not be altogether inconceivable if the same man, who as a young scholar introduced the analogy of being into the earlier tradition

71 SH I, P2, Tr1, Q1, C2, Ar1 (n. 334), Respondeo, p. 495.

72 SH I, P2, Tr1, Q1, C2, Ar2 (n. 335), Respondeo, p. 496: 'Quaedam (...) sunt quae uno modo dicuntur proprie, alio modo improprie.'

73 SH I, P2, Tr1, Q1, C2, Ar2 (n. 335), Respondeo, p. 496.

74 SH I, P2, Tr1, Q1, C2, Ar1 (n. 334), Ad obiecta 1, p. 495. John insists that the name Qui est names God without any comparison with creatures, although he does allow that the privation, non ab alio, could be construed as a kind of comparison.

75 SH I, P2, Tr1, Q1, C2, Ar2 (n. 335), Respondeo, p. 496: '[I]lla nomina, quae significant speciem sine materia vel perfectionem naturae, verius attribuit ipsi causae quam ipsis effectibus. Unde secundum hanc viam in Deo dicetur bonitas proprie et veritas et huiusmodi; et multo magis proprie quam de creatura, quia ibi est bonitas et veritas et potentia per essentiam, in creatura vero per participationem.' 
sine praeiudicio, gave it a tentative, but more definitive shape in the Summa Halensis. Without more manuscript witnesses to John's De divinis nominibus and a more complete study of the entire work, it will remain impossible to say for sure. But it does at least appear that the De divinis nominibus set the tone, and in some sense the pattern, according to which the Summa Halensis would attempt to engage the late $12^{\text {th }}$ - and early $13^{\text {th }}$-century Latin tradition of knowing and naming God.

By tracking John's use of William of Auxerre and examining the Summa Halensis' relationship with John's earlier work, we can see more clearly one part of the process by which the $13^{\text {th }}$ century Latin tradition moved towards analogy. In the works studied above, it began with John taking the metaphysical arguments that William used to defend the integrity of the earlier, grammatical tradition, and inserting those arguments into the grammatical tradition. It continued with John's adoption the res / modus distinction as a way to preserve as much of the grammatical tradition as possible: by detaching the res significata of names said with a concrete modus significandi from any reference to creatures, John was able to suggest a way in which God might be named from creatures according to the via eminentiae, without therefore carrying over any signification drawn from the human disciplines into our speech about God. But by the time of the Summa Halensis, either John or someone following in his footsteps appears to have thought so highly of this solution that he allowed it to replace the earlier tradition, classifying names said in this manner as nomina negativa, and reserving the way of eminence for something more radically kataphatic: names which deny the concrete modus significandi and affirm that a res significata drawn from creatures can be predicated proprie of God. With this latter possibility, the Summa Halensis took a definitive step beyond the grammatical tradition, and helped to usher in a new philosophical and theological era: suggesting at last that signification drawn from the human disciplines can and should be carried over into our speech about God. ${ }^{76}$

76 It is commonly thought that in the period after the Summa Halensis there began to be a divergence between Franciscan and Dominican theologians concerning how we speak of God proprie, with Franciscan explanations of analogy leaning in the direction of univocity, and Dominican explanations leaning in the direction of equivocity. But the conclusions reached in this chapter suggest that the reality may in fact be far more complex. In Book 1, d. 22, q. 1, of Thomas Aquinas' Scriptum super libros Sententiarum magistri Petri Lombardi, vol. 1, ed. Pierre Mandonnet (Paris: Lethielleux, 1929), 531-42, Aquinas engages the tradition mediated through John and the Summa Halensis, advancing from the question of whether God is nameable (a. 1), to the question of whether God is nameable proprie (a. 2), to the question of whether there is only one name for God (a. 3), to the question of the categorization of divine names (a. 4). His responses closely parallel those of John and the Summa Halensis. Not only does Aquinas closely follow them on whether the analogy of being names God proprie, he may also follow-at least initially-the Summa Halensis on how. In Book 1, d. 35, q. 1, a. 4, (Mandonnet, 818-21), Aquinas distinguishes an analogy based on priority and posteriorty from an analogy based on creatures imitating the creator. As Aquinas explains these two kinds of analogy, the former is very close to the analogy of being expressed in John's De divinis nominibus as well as the negative names of the Summa Halensis, while the latter is very close to the names of eminence 
in the Summa Halensis. Aquinas rejects the first as reducing to a form of univocation, presumably because he thinks that it reduces to some form of Praepositinus' understanding of divine predication, but he affirms the second as an adequate expression of analogy. Although, therefore, there exist significant epistemological differences between the Summa Halensis and Aquinas' Scriptum super Sententiis, these passages suggest that the influence of John of La Rochelle and the Summa Halensis on subsequent discussions of analogy may not have been confined to the Franciscan tradition, and that there may be a greater degree of inter-relatedness between Franciscans and Dominicans on the question of analogy than is commonly thought. 
